\title{
Survey of human immunodeficiency virus infection and sexually transmitted diseases in homosexual and bisexual men attending genitourinary medicine clinics in the UK during 1986-88
}

\author{
The British Cooperative Clinical Group
}

\begin{abstract}
A multicentre investigation was made into the prevalence of sexually transmitted diseases and HIV infection amongst homosexual/bisexual (HS/BS) men attending genitourinary medicine clinics in the UK during the final quarters of 1986,1987 , and 1988 . The results from individual clinics have been collated into regional groupings in order to assess geographical and temporal trends. A statistical analysis has also been performed on the data from 19 large teaching hospital clinics which contributed to both the 1986 and 1988 studies. There was a marked decline in the numbers of HS/BS men attending clinics and a statistically significant decrease in the prevalence of infectious syphilis and gonorrhoea. Although there was a concomitant fall in HIV testing rates, the prevalence of newly detected HIV antibody positive patients remained virtually constant. In $1988,12 \cdot 2 \%$ of $544 \mathrm{HS} / \mathrm{BS}$ men attending clinics in the Thames regions compared with $5.9 \%$ of 895 attending clinics elsewhere in the UK were found to be seropositive. No less than $30 \%$ of the 122 newly diagnosed individuals had been seronegative at a previous test during $1987 / 88$. In addition to these new diagnoses, there were 953 attenders who had been previously diagnosed as being HIV seropositive. Total HIV seropositivity rates amongst $\mathrm{HS} / \mathrm{BS}$ attenders ranged from $15-29 \%$ in different regions. These overall figures may underestimate the true size of the seropositive HS/BS clinic population because of the large number of untested individuals which constituted $33-51 \%$ of clinic attenders. The proportion of seropositives with clinical manifestations of chronic HIV infection was
\end{abstract}

The British Cooperative Clinical Group

Hon Secretary, G R Kinghorn, Dept of Genito-Urinary Medicine, Royal Hallamshire Hospital, Sheffield S10 2JF, UK
$54 \%$ nationally and was highest in the Thames regions and lowest in North England. Despite changes in the sexual behaviour of HS/BS men in the UK during the mid-eighties, a large proportion have been infected with HIV which has become the most widespread and prevalent sexually transmitted disease in patients attending genitourinary medicine clinics.

The long established British Cooperative Clinical Group consists of consultant physicians in genitourinary medicine and seeks to perform collaborative research in all STD clinics within the UK. Until recently, the published research on HIV infection in the UK had largely emanated from the London clinics. ${ }^{1-4}$ Apart from a few provincial centres, ${ }^{5}$ there was little information about the prevalence of STD and HIV infection in homosexual/bisexual (HS/BS) men elsewhere in the UK. It was therefore agreed to seek nationwide information about STD/HIV in this patient group in order to determine geographical and temporal trends over a three year period. Additionally, in 1988, more detailed information was sought about the clinical status of HIV infected persons attending genitourinary medicine clinics.

\section{Patients and methods}

Information was sought about homosexual/bisexual (HS/BS) men attending each clinic in the UK during the final quarters (October 1-December 31) of 1986, 1987 , and 1988. Questionnaires were sent directly to the consultants in charge of each clinic by regional representatives of the BCCG, in the August preceding each study period, in order to facilitate the prospective recording of data.

In 1986 and 1987 the study questionnaire was similar. Specific questions were asked about:

the numbers of newly presenting HS/BS men during the study period;

the numbers of these individuals found to be infected with syphilis, gonorrhoea, and other STD (conditions classified by codes $\mathrm{C} 1$ to $\mathrm{C} 12$ in the 
SBH60 clinic report);

the numbers of these individuals who consented to HIV antibody testing;

the numbers of these tested individuals who were HIV antibody positive.

In 1988, the questionnaire was supplemented with additional requests concerning:

the numbers of previously diagnosed HIV antibody positive HS/BS men who also attended during the study period;

the numbers of all HIV infected HS/BS attenders who were known to have had a prior negative HIV antibody test during 1987/88;

the current clinical status of all HIV infected HS/ BS attenders.

Data obtained from all respondents have been compared for each of the study periods. In order to minimise possible distortions caused by small numbers, the results from individual Regional Health Authorities have been grouped into larger geographical areas:

Northern, North Western, Mersey, YorkshireNORTH ENGLAND

Trent, West Midlands, East Anglia-MID ENGLAND

South Western, Oxford, Wessex-SOUTH ENGLAND

All four Thames Regions-THAMES

Scotland, Wales, Northern Ireland-OTHER UK.

There are a total of 157 clinics in England (45 North, 34 Mid, 34 South, 42 Thames), 20 clinics in Scotland, 12 clinics in Wales, and 3 clinics in Northern Ireland. About three-quarters of the total are small part-time clinics with less than 10,000 annual attendances. Traditionally, most homosexual and bisexual men have preferred to attend the larger, full-time city clinics, especially those based at the teaching hospitals in the UK, where it is easier to preserve anonymity.

A "within clinic" comparison of results from 19 large teaching hospital clinics who responded to the questionnaires in both 1986 and 1988 was also performed and subjected to statistical analysis using chi square tesi with Yates correction.

\section{Results}

Number of clinics responding (table 1)

Completed questionnaires were returned by a total of 117 (25 teaching hospital) clinics in 1986, 91 (19 teaching hospital) clinics in 1987, and 131 (23 teaching hospital) clinics in 1988. Consistently, there was in excess of two-thirds of all clinics in North and Mid England who responded in each year of the study. Further south and outside England there was less participation, nevertheless, in each study year $>50 \%$ of all clinics ( $>66 \%$ teaching centres) returned completed questionnaires.

\section{Numbers of homosexual/bisexual men attending (table 1)}

The number of HS/BS men attending fell from 7736 in 1986 to 2958 in 1987 and then rose to 4354 in 1988. In 1988, this total consisted of 953 old attenders with known HIV infection and 3401 new presenters. For each study year, both the total and average clinic numbers of HS/BS men attending the Thames clinics far exceeded the numbers attending in other regions.

Although the decline in total numbers of attenders between 1986 and 1987 was contributed to by the reduction in the numbers of participating clinics (particularly from the large centres in North West Thames which contributed results for only the 1986 study period), there was also a fall in the average number of HS/BS men attending each clinic throughout the UK. The subsequent increase recorded between 1987 and 1988 reflected the increase in participating clinics as well as the inclusion of known HIV positives undergoing regular follow up within the total attender figures.

The core of 19 teaching hospital clinics (all 12 in provincial England, 3 of 12 London teaching hospitals, and 4 of 5 in Scotland, Wales and Northern Ireland) participating in both 1986 and 1988 contributed 3504 ( $45 \%$ of the national total) attenders in 1986 and 2491 ( $57 \%$ of the national total) attenders in 1988. In 1988 this number included $666 \mathrm{HS} / \mathrm{BS}$ men known previously to be HIV positive.

Prevalence of STD (table 2)

The number of new cases of infectious syphilis in

Table 1 Number of homosexual/bisexual attenders

\begin{tabular}{|c|c|c|c|c|c|c|c|c|c|}
\hline \multirow[b]{2}{*}{ Year } & \multicolumn{3}{|c|}{ No clinics responding } & \multicolumn{3}{|c|}{ No homosexual/bisexual attenders } & \multicolumn{3}{|c|}{ Attenders per clinic mean (SD) } \\
\hline & 1986 & 1987 & 1988 & 1986 & 1987 & 1988 & 1986 & 1987 & 1988 \\
\hline $\begin{array}{l}\text { Region } \\
\text { North } \\
\text { Mid } \\
\text { South } \\
\text { Thames } \\
\text { Other UK }\end{array}$ & $\begin{array}{l}36 \\
30 \\
13 \\
18 \\
20\end{array}$ & $\begin{array}{r}31 \\
26 \\
17 \\
12 \\
5\end{array}$ & $\begin{array}{l}38 \\
31 \\
12 \\
27 \\
23\end{array}$ & $\begin{array}{r}927 \\
959 \\
512 \\
4913 \\
425\end{array}$ & $\begin{array}{r}492 \\
487 \\
431 \\
1356 \\
192\end{array}$ & $\begin{array}{r}646 \\
642 \\
354 \\
2445 \\
267\end{array}$ & $\begin{array}{c}26(48) \\
32(47) \\
39(37) \\
273(457) \\
21(37)\end{array}$ & $\begin{array}{c}17(31) \\
19(18) \\
25(35) \\
113(166) \\
38(29)\end{array}$ & $\begin{array}{l}17(31) \\
23(33) \\
30(29) \\
98(209) \\
12(22)\end{array}$ \\
\hline Total & 117 & 91 & 131 & 7736 & 2958 & 4354 & 66 (204) & $33(73)$ & $31(97)$ \\
\hline
\end{tabular}


Table $2 a \quad$ Number of cases of sexually transmitted diseases

\begin{tabular}{|c|c|c|c|c|c|c|c|c|c|}
\hline \multirow[b]{2}{*}{ Year } & \multicolumn{3}{|c|}{ Syphilis } & \multicolumn{3}{|c|}{ Gonorrhoea } & \multicolumn{3}{|c|}{ Other STD } \\
\hline & 1986 & 1987 & 1988 & 1986 & 1987 & 1988 & 1986 & 1987 & 1988 \\
\hline $\begin{array}{l}\text { Region } \\
\text { North } \\
\text { Mid } \\
\text { South } \\
\text { Thames } \\
\text { Other UK }\end{array}$ & $\begin{array}{r}12 \\
6 \\
5 \\
23 \\
1\end{array}$ & $\begin{array}{l}5 \\
2 \\
3 \\
3 \\
1\end{array}$ & $\begin{array}{r}4 \\
5 \\
1 \\
10 \\
2\end{array}$ & $\begin{array}{r}50 \\
23 \\
8 \\
157 \\
25\end{array}$ & $\begin{array}{r}22 \\
8 \\
11 \\
62 \\
4\end{array}$ & $\begin{array}{r}13 \\
13 \\
9 \\
78 \\
4\end{array}$ & $\begin{array}{r}236 \\
222 \\
113 \\
1367 \\
228\end{array}$ & $\begin{array}{r}151 \\
152 \\
69 \\
436 \\
133\end{array}$ & $\begin{array}{r}196 \\
179 \\
81 \\
719 \\
83\end{array}$ \\
\hline UK Total & 56 & 14 & 22 & 263 & 107 & 117 & 2166 & 941 & 1258 \\
\hline$\%$ attenders & $(0 \cdot 7)$ & $(0.5)$ & $(0.5)$ & $(3.4)$ & $(3 \cdot 6)$ & $(2 \cdot 7)$ & $(28 \cdot 0)$ & $(32 \cdot 0)$ & $(28.9)$ \\
\hline
\end{tabular}

Table $2 b$ Prevalence of STD in core teaching hospitals

\begin{tabular}{|c|c|c|c|c|c|c|c|c|c|c|c|c|c|c|c|c|c|}
\hline & \multicolumn{2}{|c|}{$\begin{array}{l}\text { Total } H S / B S \\
\text { attenders }\end{array}$} & \multicolumn{5}{|c|}{ No (\%) with syphilis } & \multicolumn{5}{|c|}{ No (\%) with gonorrhoea } & \multicolumn{5}{|c|}{ No (\%) with other STD } \\
\hline & $\begin{array}{l}1986 \\
\text { No }\end{array}$ & $\begin{array}{l}1988 \\
\text { No }\end{array}$ & $\begin{array}{l}1986 \\
\text { No }\end{array}$ & $\%$ & $\begin{array}{l}1988 \\
\text { No }\end{array}$ & $\%$ & $p$ & $\begin{array}{l}1986 \\
\text { No }\end{array}$ & $\%$ & $\begin{array}{l}1988 \\
\text { No }\end{array}$ & $\%$ & $p$ & $\begin{array}{l}1986 \\
\text { No }\end{array}$ & $\%$ & $\begin{array}{l}1988 \\
\text { No }\end{array}$ & $\%$ & $p$ \\
\hline $\begin{array}{l}\text { England } \\
\text { Provincial } \\
\text { London } \\
\text { Other UK }\end{array}$ & $\begin{array}{r}1349 \\
1853 \\
302\end{array}$ & $\begin{array}{r}957 \\
1335 \\
199\end{array}$ & $\begin{array}{r}9 \\
14 \\
7\end{array}$ & $\begin{array}{l}0.7 \\
0.8 \\
2 \cdot 3\end{array}$ & $\begin{array}{l}6 \\
2 \\
0\end{array}$ & $\begin{array}{l}0.6 \\
0.1\end{array}$ & $\begin{array}{l}\text { NS } \\
<0.05 \\
\text { NS }\end{array}$ & $\begin{array}{l}44 \\
71 \\
15\end{array}$ & $\begin{array}{l}3 \cdot 3 \\
3 \cdot 8 \\
5 \cdot 0\end{array}$ & $\begin{array}{r}18 \\
30 \\
3\end{array}$ & $\begin{array}{l}1 \cdot 9 \\
2 \cdot 2 \\
1 \cdot 5\end{array}$ & $\begin{array}{l}\text { NS } \\
<0.02 \\
\text { NS }\end{array}$ & $\begin{array}{l}293 \\
742 \\
174\end{array}$ & $\begin{array}{l}21 \cdot 7 \\
40 \cdot 0 \\
57 \cdot 6\end{array}$ & $\begin{array}{r}232 \\
245 \\
63\end{array}$ & $\begin{array}{l}24 \cdot 2 \\
18 \cdot 4 \\
31 \cdot 7\end{array}$ & $\begin{array}{l}\text { NS } \\
0.001 \\
0.001\end{array}$ \\
\hline All UK & 3504 & 2491 & 30 & 0.9 & 8 & 0.3 & $<0.02$ & 130 & $3 \cdot 7$ & 51 & $2 \cdot 0$ & $<0.001$ & 1209 & $34 \cdot 5$ & 540 & $21 \cdot 7$ & 0.001 \\
\hline
\end{tabular}

attenders declined from 56 in 1986 to 22 cases in 1988. Thus, the prevalence of syphilis in attenders was less than $1 \%$ for each study period.

The number of new cases of gonorrhoea also fell from a total of $263(3.4 \%)$ in 1986 to $117(2.7 \%)$ in 1988.

There was, however, no alteration in the proportion of attenders found to have other STD; this remained virtually constant at around $30 \%$ for each study period.

Amongst attenders at the core teaching hospital clinics (table 2A), between 1986 and 1988, there was: a significant fall in the prevalence of infectious syphilis from $0.9 \%$ to $0.3 \%(p<0.02)$; a significant fall in the prevalence of gonorrhoea from $3.7 \%$ to $2.0 \%(\mathrm{p}<0.001)$; and a significant fall in the prevalence of other STD from $34.5 \%$ to $21.7 \%$ (p < 0.001 ). These changes were largely the result of decreasing rates of infection amongst attenders at the London teaching centres which had been higher in 1986 but were virtually identical in 1988 to those in provincial centres.

\section{HIV testing rates (table $3 a$ )}

There was a marked fall in the numbers of attenders who underwent HIV antibody testing between 1986 and 1988. The proportions of all attenders, not known previously to be HIV antibody positive, who underwent testing declined from $55 \%$ in 1986 to $42 \%$ in 1988 . Although this decline in testing rates occurred throughout the UK, it was again most marked in the Thames regions. In 1986, HIV antibody testing rates varied between $47 \%$ in
Thames and $83 \%$ in North England, as compared with a low of $30 \%$ in Thames and a high of $61 \%$ in Mid England in 1988. In the core teaching hospitals (table 3b), HIV antibody testing rates significantly declined from $68 \%$ in 1986 to $43 \%$ in 1988 (p < 0.001).

\section{Prevalence of newly diagnosed HIV infection}

The number of newly diagnosed HIV seropositive men declined from 434 to 122 in the final quarters of 1986 and 1988 respectively. Amongst tested attenders, the overall prevalence of newly diagnosed HIV infection was $10 \%$ in $1986,13 \%$ in 1987 , and $9 \%$ in 1988. In 1988, this prevalence varied between $5 \%$ in North England and $12 \%$ in Thames. In the core teaching hospitals, there was no significant change in the prevalence of newly diagnosed HIV infection between the observed $9.8 \%$ in 1986 and $8.7 \%$ in 1988. Nevertheless, in all Regions, the prevalence of newly diagnosed HIV infection greatly exceeded the prevalence of infectious syphilis and/or gonorrhoea.

Seroconversions in $1987 / 88$

A total of 36 men, representing $30 \%$ of all newly diagnosed HIV infected patients, $3 \%$ of all HIV seropositives, and $1.1 \%$ of all 3401 attenders in 1988 whose HIV status was unknown, were known to have had an earlier negative HIV antibody test result during 1987 and/or 1988.

HIV status of attenders in 1988 (table 4)

In the 1988 study period, $953(22 \%)$ attenders were previously known to be HIV positive. The total 
Table $3 a$

\begin{tabular}{|c|c|c|c|c|c|c|}
\hline \multirow[b]{2}{*}{ Year } & \multicolumn{3}{|c|}{ Numbers $(\%)$ tested for anti-HIV } & \multicolumn{3}{|c|}{ Numbers $(\%)$ positive for anti-HIV } \\
\hline & 1986 & 1987 & $1988^{\star}$ & 1986 & 1987 & 1988 \\
\hline $\begin{array}{l}\text { Region } \\
\text { North } \\
\text { Mid } \\
\text { South } \\
\text { Thames } \\
\text { Other UK }\end{array}$ & $\begin{array}{r}772(83) \\
620(65) \\
328(64) \\
2313(47) \\
257(60)\end{array}$ & $\begin{array}{r}323(66) \\
285(58) \\
286(66) \\
528(39) \\
81(42)\end{array}$ & $\begin{array}{l}292(55) \\
325(61) \\
163(52) \\
544(30) \\
105(48)\end{array}$ & $\begin{array}{c}49(6 \cdot 4) \\
27(4 \cdot 4) \\
16(4 \cdot 9) \\
330(14 \cdot 3) \\
12(4 \cdot 7)\end{array}$ & $\begin{array}{c}28(8 \cdot 7) \\
21(7 \cdot 4) \\
11(3 \cdot 9) \\
128(24 \cdot 2) \\
8(9 \cdot 9)\end{array}$ & $\begin{array}{c}15(5 \cdot 1) \\
19(5 \cdot 9) \\
10(6 \cdot 1) \\
70(12 \cdot 2) \\
8(7 \cdot 7)\end{array}$ \\
\hline Total & $4290(55)$ & $1503(51)$ & $1429(42)$ & $434(10 \cdot 1)$ & $196(13.0)$ & $122(8 \cdot 5)$ \\
\hline
\end{tabular}

^Denominator excludes known HIV positives.

Table $3 b \quad H I V$ antibody testing and new positives in core teaching hospitals

\begin{tabular}{|c|c|c|c|c|c|c|c|c|c|c|c|c|}
\hline & \multicolumn{2}{|c|}{ Total $H S / B S$ attenders } & \multicolumn{5}{|c|}{ No $(\%)$ tested for HIV antibody } & \multicolumn{5}{|c|}{ No $(\%)$ HIV antibody positive } \\
\hline & $\begin{array}{l}1986 \\
\text { No }\end{array}$ & $\begin{array}{l}1988 \\
\text { No }\end{array}$ & $\begin{array}{l}1986 \\
\text { No }\end{array}$ & $\%$ & $\begin{array}{l}1988 \\
\text { No }\end{array}$ & $\%$ & $p$ & $\begin{array}{l}1986 \\
\text { No }\end{array}$ & $\%$ & $\begin{array}{l}1988 \\
\text { No }\end{array}$ & $\%$ & $p$ \\
\hline $\begin{array}{l}\text { England } \\
\text { Provincial } \\
\text { London } \\
\text { Other UK }\end{array}$ & $\begin{array}{r}1349 \\
1853 \\
302\end{array}$ & $\begin{array}{l}790 \\
858 \\
174\end{array}$ & $\begin{array}{r}995 \\
1238 \\
153\end{array}$ & $\begin{array}{l}73 \cdot 8 \\
66 \cdot 8 \\
50 \cdot 7\end{array}$ & $\begin{array}{r}450 \\
256 \\
80\end{array}$ & $\begin{array}{l}57 \cdot 0 \\
29 \cdot 8 \\
46 \cdot 0\end{array}$ & $\begin{array}{l}<0.001 \\
<0.001 \\
\text { NS }\end{array}$ & $\begin{array}{r}55 \\
169 \\
11\end{array}$ & $\begin{array}{r}5.5 \\
13 \cdot 7 \\
7.2\end{array}$ & $\begin{array}{r}22 \\
43 \\
3\end{array}$ & $\begin{array}{r}4.9 \\
16 \cdot 8 \\
3.8\end{array}$ & $\begin{array}{l}\text { NS } \\
\text { NS } \\
\text { NS }\end{array}$ \\
\hline All UK & 3504 & 1822 & 2386 & $68 \cdot 1$ & 786 & $43 \cdot 1$ & $<0.001$ & 235 & 9.8 & 68 & $8 \cdot 7$ & NS \\
\hline
\end{tabular}

number of HIV positive $\mathrm{HS} / \mathrm{BS}$ attenders in the UK was 1075, giving an overall prevalence rate of $25 \%$. HIV seropositivity rates varied from $15 \%$ in South England to $29 \%$ in the Thames regions. The proportions with unknown HIV status varied widely, being highest in the Thames regions $(51 \%)$ and lowest in the Midlands (33\%).

The overall HIV prevalence figure is subject to considerable distortion because of the high proportion of untested patients. If tested patients alone are considered, the prevalence of HIV seropositivity was found to exceed $60 \%$ in the Thames regions and was about $30 \%$ in the rest of the UK (fig 1).

Clinical status of $H I V$ seropositives (fig 2)

A history of seroconversion illness was reported for only $19(2 \%)$ of all HIV infected patients. Overall, $20 \%$ already had AIDS, $16 \%$ had other CDC group IV disease, $18 \%$ had persistent generalised lymphadenopathy, and $46 \%$ were asymptomatic. There

Table 4 HIV status of homosexual/bisexual men, $G U$ medicine clinics, UK, Oct-Dec 1988

\begin{tabular}{|c|c|c|c|c|c|c|}
\hline & \multicolumn{2}{|c|}{ Positive } & \multicolumn{2}{|c|}{ Negative } & \multicolumn{2}{|c|}{ Unknown } \\
\hline & $N o$ & $\%$ & No & $\%$ & No & $\%$ \\
\hline $\begin{array}{l}\text { North } \\
\text { Mid } \\
\text { South } \\
\text { Thames } \\
\text { Other UK }\end{array}$ & $\begin{array}{r}128 \\
127 \\
53 \\
718 \\
49\end{array}$ & $\begin{array}{l}(20) \\
(20) \\
(15) \\
(29) \\
(18)\end{array}$ & $\begin{array}{r}277 \\
306 \\
153 \\
474 \\
97\end{array}$ & $\begin{array}{l}(43) \\
(48) \\
(43) \\
(19) \\
(36)\end{array}$ & $\begin{array}{r}241 \\
153 \\
148 \\
1253 \\
121\end{array}$ & $\begin{array}{l}(37) \\
(33) \\
(42) \\
(51) \\
(45)\end{array}$ \\
\hline Total UK & 1075 & (25) & 1307 & (30) & 1972 & (45) \\
\hline
\end{tabular}

was geographical variation in the relative proportions in each clinical category. The proportion with HIV related clinical manifestations was highest in Thames, and lowest in North England.

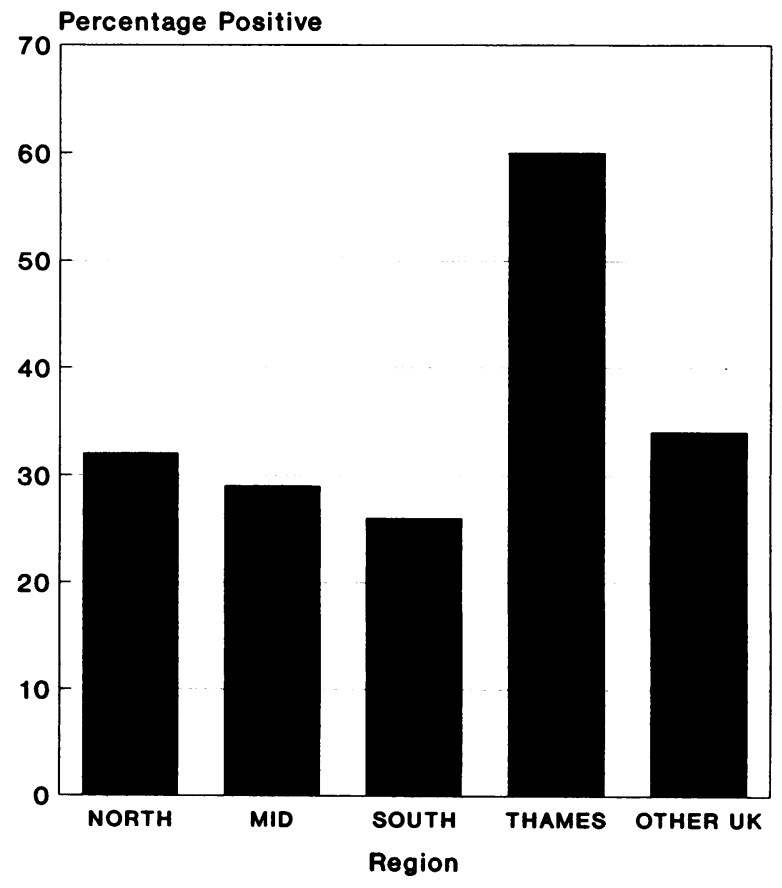

Figure 1 HIV status of tested patients 

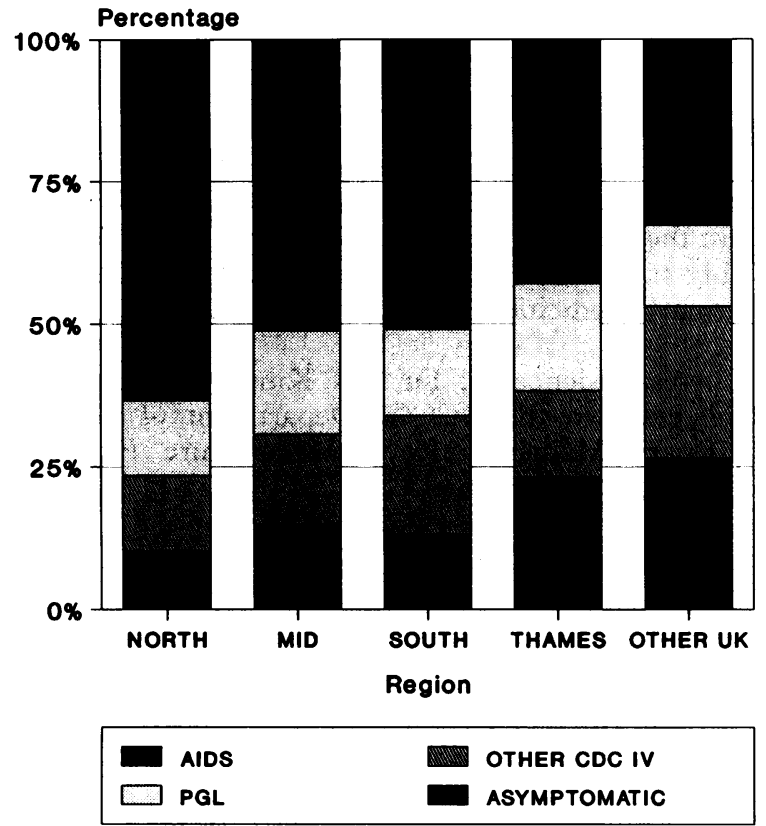

Figure 2 Clinical status of HIV positives

\section{Discussion}

Genitourinary medicine clinics uniquely combine important roles in the surveillance of sentinel populations, the management of infected patients, and the prevention of transmission of HIV/AIDS. The initial impact of HIV/AIDS has been particularly apparent in the large London clinics where there have long been large populations of gay attenders. This study indicates that HIV infection has also become widespread amongst the smaller populations of HS/BS men attending clinics elsewhere in the UK. The first study period, in late 1986 , coincided with intensive media exposure and heightened public concern about AIDS. This resulted in large numbers of patients, of all sexual orientations, presenting to clinics for reassurance and testing. It is therefore not surprising that there was a fall in HS/BS men attending in subsequent study periods. The 1986 results also included data from the large clinics in NW Thames, including three of the major centres for AIDS, which did not participate in the second and third years of the study. Although the absence of data from these centres, which also see large numbers of patients with other STD, in subsequent study years might itself account for the apparent trends in national figures, the "within clinic" comparison of data from teaching hospitals did confirm significant downward trends in the numbers of HS/BS attenders, their incidence and prevalence of STDs, and in HIV testing rates.

The decline in cases of syphilis and gonorrhoea throughout the UK during study period is consistent with the previously reported trends in homosexually acquired STD in London clinics. ${ }^{67}$ Both diseases are now uncommon in this patient group. Johnson and Gill, ${ }^{8}$ who additionally showed a falling incidence of hepatitis B amongst homosexual men, described STD rates falling from 1985 onwards. Nevertheless, there are no grounds for complacency. The "withinclinic" analysis suggested that the downward trend was marked in London but minimal or absent in the English provinces. Over the whole UK, in each study year approximately one third of all attenders had STD other than gonorrhoea, syphilis or HIV infection. It appears that many attenders are still adopting sexual practices which are not sufficiently safe to prevent their acquiring STD which may also predispose to sexual acquisition of HIV infection. This study was not designed to determine whether the prevalence of other STD in known HIV seropositives differs from that in those who are HIV negative or whose status is unknown. Such information is important, not least for auditing the effectiveness of patient counselling, and will be subject to future study.

Rates of HIV testing declined generally amongst HS/BS attenders during the study period, even after known HIV positive attenders were excluded from the analysis. The lowest rates of testing occurred in the highest prevalence areas. It will be interesting to see whether testing rates increase in the light of reports suggesting that early antiviral treatment may improve prognosis. Certainly, those with unknown HIV status may be denying themselves, and their partners, the potential clinical benefits which could arise from early diagnosis and consequent lifestyle changes.

The prevalence of newly diagnosed HIV infection now far exceeds the prevalence of either syphilis and/ or gonorrhoea. There was no significant fall between 1986 and 1988 in the proportion of tested patients who had newly recognised HIV infection. The HIV antibody prevalences obtained in 1986, both for patients in the Thames regions and those in the provinces, were very similar to the $15.2 \%$ and $6.3 \%$, respectively, reported by the PHLS/Genitourinary Medicine Collaborative Group. ${ }^{9}$ That study involved a smaller number of clinics and tested patients. In 1988, we found HIV positivity rates of $12.2 \%$ in $544 \mathrm{HS} / \mathrm{BS}$ men attending Thames clinics compared with $5.8 \%$ in $895 \mathrm{HS} / \mathrm{BS}$ men attending clinics elsewhere in the UK.

Seroconversion in 1987/88 was reported for $30 \%$ of all newly diagnosed seropositives reported in the 1988 study period. This is a substantial proportion and could be an underestimate because many newly diagnosed cases of HIV infection were in people who had not been previously tested. Nevertheless, because this study was limited to the final quarters of 
each year, we do not have figures for either the total patients with negative tests in 1987 nor their numbers who tested positive in 1988 with which to calculate a true seroconversion rate.

Amongst all HS/BS men attending clinics during the final quarter of 1988 (including those already known to be HIV antibody positive), the overall prevalence of HIV infection was $25 \%$, ranging between $15 \%$ in the South England clinics and $29 \%$ in the Thames clinics. These statistics could underestimate the true proportion of HIV positives. If only those tested are considered, the overall prevalence of HIV infection in the 1988 attenders throughout the UK was $45 \%$, ranging from $26 \%$ in the South England clinics to $60 \%$ in the Thames clinics. Thus, HIV infection is now widely prevalent amongst clinic attenders throughout the UK. Although this figure is likely to be higher than that obtained from point prevalence studies because of the bias produced by the selection of known positive patients for continuing clinical monitoring and care, it has been shown in other studies that HIV infection rates in at-risk men declining testing is likely to be higher than in tested patients. ${ }^{2}$ The implications for patient management of these results are that untested HS/BS patients should be offered the same initial counselling, long term follow up, and monitoring as known HIV positives in order to try to maximise the benefits of early diagnosis of immune deficiency and to minimise further transmission.

In terms of related clinical manifestations, the study suggests that acute seroconversion illness is rare, being reported for only $2 \%$ of HIV infected patients. This figure is similar to that reported by Cooper et al in $1985 . .^{10}$ Manifestations of chronic HIV infection were present in over $50 \%$ of seropositives which suggests that their infections are longstanding. The larger proportions of asymptomatics attending the provincial clinics could reflect later spread to the populations outside London, but may also reflect regional differences in clinic policy about the importance of testing to detect early infection.

In conclusion, HIV appears to be the most prevalent of all STD amongst HS/BS men throughout the UK and its associated morbidity will inevitably be a cause of increasing workload in genitourinary medicine clinics in the near future.

Correspondence to: Dr GR Kinghorn, Honorary Secretary to the BCCG, Department of GenitoUrinary Medicine, Royal Hallamshire Hospital, Glossop Road, Sheffield S10 2JF, UK.

1 Carne CA, Weller IVD, Sutherland S, et al. Rising prevalence of human T-cell lymphotropic virus type III (HTLV-III infection in homosexual men in London). Lancet 1985;i:1261-2.

2 Carne CA, Weller IVD, Johnson AM, et al. Prevalence of antibodies to human immunodeficiency virus (HIV), gonorrhoea rates and altered sexual behaviour in homosexual men in London. Lancet 1987;i:656-8.

3 Evans BA, Dawson SG, McLean KA, et al. Sexual Lifestyle and clinical findings related to HTLV III/LAV status in homosexual men. Genitourin Med 1986;62:384-9.

4 Weber JN, Wadsworth J, Rogers LA, et al. Three-year prospective study of HTLV III/LAV infection in homosexual men. Lancet 1986;i:1179-82.

5 Arya OP, Carey PB, Turner GC, Egerton M, Brown C, Tait A. HIV infection in Liverpool, England. Arch of AIDS Res 1987;1:87-95.

6 Gellan MCA, Ison CA. Declining incidence of gonorrhoea in London: a response to fear of AIDS? Lancet 1986;i:920.

7 Carne CA, Weller IVD, Sonnex C, Johnson AM, Petherick AM, Adler MW. Heterosexual transmission of HIV infection. Lancet 1987; ;i: 41 .

8 Johnson AM, Gill ON. Evidence for recent changes in sexual behaviour in homosexual men in England and Wales. Phil Trans $R$ Soc Lond $B$ 1989;325:153-61.

9 Polakoff S. HIV infection in patients attending clinics for sexually transmitted diseases in England and Wales. Br Med J 1989;298:415-8.

10 Cooper DA, Gold J, Mackan P, et al. . Acute AIDS retrovirus infection. Lancet 1985;i:537-40.

Accepted for publication 2 May 1990 